\title{
T8 - Evaluación del crecimiento de Pinabete (Abies guatemalensis Rehder) a través de plantas nodrizas
}

\author{
Gesly A. Bonilla-Landaverry*, Sindy Y. González-Sánchez \\ Centro Universitario de Sur Oriente, Universidad de San Carlos de Guatemala
}

*Autor al que se dirige la correspondencia: gesly77@hotmail.com

\section{Resumen}

$\mathrm{E}$ 1 pinabete (Abies guatemalensis Rehder) es una especie sumamente importante desde el punto de vista, ecoClógico, social y económico, lo que hace que sea una de las especies forestales mayormente amenazadas en Guatemala. Su aprovechamiento ha sido a una tasa superior a su regeneración natural, principalmente en época navideña, donde su corte y comercialización se considera ilegal y en época navideña su demanda se incrementa como árbol ornamental, debido a sus características morfológicas, diseño de la planta y aroma característico. Con el objeto de mejorar su reproducción se realizó un ensayo experimental para evaluar el efecto que tienen una serie de plantas sobre el crecimiento del pinabete. A este tipo de plantas que le brindan humedad, calor, nutrientes y protección a los árboles que están en crecimiento por regeneración natural o por trasplante se le denomina planta nodriza. La variable evaluada fue el crecimiento en $\mathrm{mm}$ de los arbolitos de pinabete luego de 82 días de haber sido trasplantados en asocio con las plantas nodrizas. Los resultados arrojaron que el crecimiento en del pinabete se ve más favorecido cuando se encuentra en asocio con arrayán y musgo, pues en un período menor a tres meses los arbolitos de $A$. guatemalensis crecieron 2.4 y $2.1 \mathrm{~cm}$ respectivamente, mientras que con el resto de los tratamientos su crecimiento se vio limitado.

Palabras claves: Pinabete, plantas nodrizas, reproducción, especie endémica

\begin{abstract}
$A$ bies guatemalensis Rehder is an extremely important specie from the ecological, social and economic point of view, which makes it one of the most threatened forest species in Guatemala. Its use has been above its natural regeneration, especially at Christmas time, where his cut and marketing is considered illegal and at Christmas time rate demand increases as an ornamental tree because of its morphological characteristics, plant design and aroma. In order to improve reproduction, an experimental trial was conducted to evaluate the effect that a number of plants on the growth of pinabete. This type of plants that provide moisture, heat, nutrients and protection to trees that are growing by natural regeneration or transplantation is called mother plant. The variable evaluated was the growth in $\mathrm{mm}$ of 82 days seedling after being transplanted in association with nurse plants. The results showed that growth of pinabete is more favored when found in association with arrayan and moss, because in less than three months seedling of A, guatemalensis grew 2.4 and $2.1 \mathrm{~cm}$ respectively, while for the rest, the growth was limited
\end{abstract}

Keywords: Pinabete, nurse plants, reproduction, endemic species 